\title{
Anti-proliferative and apoptosis inducing activity of Calophyllum inophyllum L. oil extracts on C6 glioma cell line
}

\author{
Ayşegül Erdemir*i[
}

Department of Molecular Biology and Genetics, Faculty of Arts \& Science, Yildiz Technical University, Esenler 34220 Istanbul, Turkey.

\section{How to cite}

Erdemir, A. (2021). Anti-proliferative and apoptosis inducing activity of Calophyllum inophyllum L. oil extracts on C6 glioma cell line. Biotech Studies, 30(1), 1-6. https://doi.org/10.38042/biost.2020.30.01.01

\section{Article History}

Received 3 December 2020

Accepted 1 January 2021

First Online 4 January 2021

\section{* Corresponding Author}

Tel.: +902123834462

E-mail: aerdemir@yildiz.edu.tr

\section{Keywords \\ Calophyllum inophyllum \\ Glioma \\ Cell cytotoxicity \\ Apoptosis \\ Antiproliferative activity}

\begin{abstract}
Glioblastoma multiforme (GBM) is one of the most lethal type of brain tumors. Current treatment methods of GBM including radiotherapy and chemotherapy are not sufficient to combat this disease and there is a great need to develop new treatment approaches. Calophyllum inophyllum L. is a polyphenol rich plant with wide biological activities. The aim of this study was to investigate cytotoxic, anti-proliferative and apoptotic activity of $\mathrm{C}$. inophyllum oil ( $\mathrm{CIO}$ ) extracts on the $\mathrm{C} 6$ glioma cell line to determine its potential use in cancer treatment. Treatment of $\mathrm{C} 6$ glioma cells with $\mathrm{ClO}$ extracts for 24 and $48 \mathrm{~h}$ were resulted in a significant decrease in cell viability with $\mathrm{IC}_{50}$ values of $0.22 \%$ and $0.082 \%$, respectively. Proliferating cell nuclear antigen labeling of $\mathrm{ClO}$ extract treated $\mathrm{C} 6$ glioma cells showed cell proliferation decreased to $55.6 \%$ and $30.3 \%$ for 24 and $48 \mathrm{~h}$. Percentage of apoptotic cells after $\mathrm{ClO}$ extract treatment were found to reach $68.8 \%$ after $48 \mathrm{~h}$. Analysis of mRNA expression levels of key genes involved in apoptosis pathway showed that $\mathrm{ClO}$ extract treatment induces both intrinsic and extrinsic apoptosis pathways on $\mathrm{C} 6$ glioma cells. Findings of this study showed that $\mathrm{ClO}$ extracts are promising in development of new treatment strategies for glioblastoma.
\end{abstract}

\section{Introduction}

Glioblastoma multiforme (GBM) is one of the most common and malignant primary brain tumor in adults. GBM grows rapidly and has a high rate of invasion and angiogenesis capacity but they often do not metastasize out of the brain. This tumor type carries the highest incident rate among brain and central nervous system tumors with the incident rate of $3.19 / 100.000$ population (Thakkar et al., 2014). On the other hand, GBM has worst prognosis among other types of brain cancers (Hanif et al., 2017) . The median survival for GBM is 15 months and less than $5 \%$ of patients survive 5 years post-diagnosis (Delgado-López \& CorralesGarcía, 2016). The standard treatment approach for
GBM is very complex, it includes surgical resection of tumor followed by radiotherapy and chemotherapy (Delgado-López \& Corrales-García, 2016). Despite optimal treatment, high resistance of tumor cells to chemotherapy and radiotherapy, GBM has very poor survival rate. Since conventional therapies not sufficient to combat this disease there is a great need to develop new treatment approaches.

Phytochemicals are natural plant derived compounds and known to be as a great source for development of many drugs. Many phytochemicals and their derivatives are known to have high antitumor potential for cancer treatment. In addition, it is known that phytochemical-based agents increase treatment efficiency and reduce most of the side effects of drugs 
(Choudhari et al., 2020). Polyphenols are one of the most diverse phytochemical groups and exhibits wide range of biological activities including anti-cancer, antiproliferative and anti-oxidant activities (Upadhyay \& Dixit, 2015). Calophyllum inophyllum L. (Calophyllaceae) is a polyphenol rich evergreen pantropical tree found in Africa, Asia, and Pacific countries (Dweck \& Meadows, 2002). Various parts of $C$. inophyllum plant such as barks, leaves, and fruits are used for different traditional medicinal purposes (Raharivelomanana et al., 2018). C. inophyllum contains wide range of phytochemicals such as triterpenoids, steroids, coumarins, and flavonoids (Susanto et al., 2019). Hence, $C$. inophyllum extracts are also known to have anti-oxidant, anti-microbial, antiviral, anti-inflammatory and anti-proliferative activities (Dweck \& Meadows, 2002). Nevertheless, studies carried out until today, mostly focused on the uses of $C$. inophyllum extracts in cosmetic industry and wound healing (Ansel et al., 2016; Raharivelomanana et al., 2018). Considering its wide biological activities $C$. inophyllum has a great potential to be used in pharmaceutical development, especially for use in cancer treatment. However, there are limited numbers of studies in the literature that have investigated the potential use of $C$. inophyllum extracts in cancer treatment (Hsieh et al., 2018; Jaikumar et al., 2016; Shanmugapriya et al., 2017).

Development of most phytochemical-based drugs begins with the in vitro investigation of anti-tumor potential of plant extract. In this study, we aimed to investigate cytotoxic, anti-proliferative and apoptotic activity of $C$. inophyllum oil extracts on the $C 6$ glioma cell line in order to determine its potential use in cancer treatment.

\section{Materials and Methods}

\section{Materials}

Pure cold-press C. inophyllum oil (100\%) (CIO) extract was purchased from EuropeVital Herbal and Aromatic Oil, Turkey. The C6 glioma cell line and $L 929$ mouse fibroblast cell line were obtained from the American Type Culture Collection (ATCC, Manassas, VA). Proliferating cell nuclear antibody (PCNA) was purchased from Thermo Scientific ${ }^{\mathrm{TM}}$, USA. ApopTag ${ }^{\circledR}$ Peroxidase In Situ Apoptosis Detection Kit was obtained from Millipore, USA. Direct-zol ${ }^{\mathrm{TM}}$ RNA MiniPrep kit (Zymo Research, Irvine, USA) was used for RNA isolation. SensiFAST ${ }^{\mathrm{TM}}$ cDNA Synthesis Kit Bioline Reagents Ltd., UK) was used for cDNA synthesis. SensiFAST ${ }^{\mathrm{TM}}$ SYBR LoRox (Bioline Reagents Ltd, London, UK) kit was used for quantitative real-time polymerase chain reaction (qRTPCR).

\section{Cell Culture}

The C6 glioma cells were cultured in Dulbecco's modified Eagle's medium (DMEM)/Ham's Nutrient Mixture F-12 medium (1:1) containing 5\% fetal bovine serum (FBS), streptomycin $(100 \mu \mathrm{g} / \mathrm{mL})$, penicillin
$(100 \mathrm{u} / \mathrm{ml})$ and I-glutamine $(0.2 \mathrm{mM})$. L929 fibroblast cells were cultured in Dulbecco's modified Eagle's medium (DMEM)/Ham's Nutrient Mixture F-12 medium (1:1) containing $10 \%$ fetal bovine serum (FBS), streptomycin $(100 \mu \mathrm{g} / \mathrm{mL})$, penicillin $(100 \mathrm{u} / \mathrm{ml})$ and Iglutamine $(0.2 \mathrm{mM})$. Cells were incubated at $37^{\circ} \mathrm{C}$ in a saturated humidity atmosphere with $5 \% \mathrm{CO}_{2}$.

\section{MTT Cell Viability assay}

The cytotoxic effect of $\mathrm{ClO}$ extract on $\mathrm{C} 6$ glioma and $\mathbf{2 9 2 9}$ fibroblast cell lines were determined using MTT (3-(4,5-dimethylthiazol-2-yl)-2,5diphenyltetrazolium bromide) assay. Cells were seeded on a 96 well plate at a density of $1 \times 10^{4} /$ well and incubated overnight. Next day, old media was removed and cells were treated with medium containing various concentrations of $\mathrm{ClO}$ and cells were cultured for 24 and 48 h. After 24 and 48 h incubation with $\mathrm{ClO}$ extract, supernatants were removed and MTT solution (50 $\mu \mathrm{g} / \mathrm{mL}$ ) was added on each well for $3 \mathrm{~h}$ incubation at $37^{\circ} \mathrm{C}$. The amount of purple formazan was determined by dissolving it in $0.1 \mathrm{~mL}$ DMSO and measuring the optical density at $570 \mathrm{~nm}$ in a microplate reader. Untreated cells were used as control group. The cytotoxic effect of $\mathrm{ClO}$ extract against $\mathrm{C} 6$ glioma cells was expressed as $I C_{50}$. Cell viability (\%) was calculated by the following equation:

$$
\text { Cell viability } \%=\frac{O D \text { value of treated cells }}{O D \text { value of control cells }} \times 100
$$

\section{Proliferating cell nuclear antibody (PCNA) cell proliferation assay}

The effect of $\mathrm{ClO}$ extract treatment on $\mathrm{C} 6$ glioma cell proliferation was determined by immunocytochemical detection of the presence of PCNA antibody as previously described (Ersoz et al., 2019). C6 glioma cells were cultured on 24 well plates at a density of $1 \times 10^{4}$ cells in wells containing coverslips. Cells were incubated until they reach confluency. Then, 24 and $48 \mathrm{~h} \mathrm{IC}_{50}$ concentration of $\mathrm{ClO}$ extracts were applied on $\mathrm{C} 6$ glioma cells. After 24 and $48 \mathrm{~h}$ incubation, cells were washed with phosphate buffered saline (PBS). Cells were fixated by ice-cold methanol treatment for five minutes. Following fixation step, blocking solution was applied and cells were incubated with PCNA primary antibody (1:300) overnight at $4^{\circ} \mathrm{C}$. After overnight incubation cells were washed again and biotinylated secondary antibodies, streptavidin, biotinylated horseradish peroxidase were applied on cells. AEC kit (Invitrogen, Camarillo, USA) was used to stain immunoreactive cells and hematoxylene was used as counterstain. Olympus BX-50 bright field microscope was used to visualize stained and unstained cells. 10 random fields were chosen, and stained/unstained cells were counted to determine the percentage of immunoreactive cells. Percentage immunoreactivity was calculated as follows: 


$$
\text { immunoreactivity } \%=\frac{\# \text { of immunoreactive cells }}{\# \text { of total cells }} \times 100
$$

\section{Terminal deoxynucleotidyl transferase-mediated dUTP nick end labeling (TUNEL) assay}

Immunocytochemical investigation of $\mathrm{ClO}$ extracts on C6 glioma cell apoptosis induction was determined by TUNEL assay according to manufacturer's protocol. C6 glioma cells were seeded on coverslips at a density of $1 \times 10_{4}$ cell per well. Then, 24 and $48 \mathrm{~h} \mathrm{IC}_{50}$ concentration of $\mathrm{ClO}$ extracts were applied on cells. Cells were fixated with ice-cold methanol followed by immediate addition of equilibration buffer. TUNEL reaction mixture (terminal deoxynucleotidyl transferase and reaction buffer with nucleotide mixture) was added on cells and incubated for $1 \mathrm{~h}$ at $37^{\circ} \mathrm{C}$. Diaminobenzidine (DAB) as the substrate of peroxidase was used to stain the DNA fragments. 10 random fields were selected to count stained/unstained cells. Percentage of apoptotic cells was determined as follows (Ersoz et al., 2019):

$$
\text { apoptotic cells } \%=\frac{\# \text { of apoptotic cells }}{\# \text { of total cells }} \times 100
$$

\section{Gene expression analysis by quantitative real-time polymerase chain reaction}

C6 glioma cells were treated with $\mathrm{IC}_{50}$ concentration of $\mathrm{ClO}$ extracts for $48 \mathrm{~h}$. Total RNA isolation from cells was performed using the Direct-zol ${ }^{\mathrm{TM}}$ RNA MiniPrep kit (Zymo Research, Irvine, USA), according to the manufacturer's instructions. After isolation, RNA integrity and concentrations were checked by using NanoDrop UV-Vis spectrophotometer. SensiFAST cDNA synthesis kit (Zymo Research, Irvine, USA) was used to synthesize cDNA from purified RNA and manufacturer's instructions were followed for synthesis. Briefly, $1 \mu \mathrm{g}$ RNA, $4 \mu \mathrm{l}$ 5x TransAmp Buffer and $1 \mu \mathrm{l}$ reverse transcriptase enzyme were mixed and reaction mixture was completed to $20 \mu \mathrm{l}$ with $\mathrm{dH}_{2} \mathrm{O}$. Then, this mixture was incubated $10 \mathrm{~min}$ at $25^{\circ} \mathrm{C}$ for primer annealing, $30 \mathrm{~min}$ at $42^{\circ} \mathrm{C}$ for reverse transcription and $5 \mathrm{~min}$ at $85^{\circ} \mathrm{C}$ for inactivation step in a thermal cycler. SensiFAST SYBR Lo-Rox kit (Bioline Reagents Ltd, London, UK) was used to detect gene amplification in qRT-PCR. Reactions were carried out using AriaMx Real-Time PCR System (Agilent
Technologies, Santa Clara, USA). Reaction conditions were $2 \mathrm{~min}$ pre-denaturation at $95^{\circ} \mathrm{C}$, denaturation at $95^{\circ} \mathrm{C}$ for $5 \mathrm{~s}$, annealing at $63^{\circ} \mathrm{C}$ for $10 \mathrm{~s}$ and elongation at $72^{\circ} \mathrm{C}$ for $15 \mathrm{~s}$ for 40 cycles. Primer pairs of target genes and housekeeping $\beta$-actin gene were listed in Table 1. The relative gene expressions of all the genes tested were determined by using $2^{-\Delta \Delta C t}$ method where $\beta$-actin gene was used as internal control (Livak \& Schmittgen, 2001) (Table 1).

\section{Statistical analysis}

Graphpad Prism software version 6 (GraphPad Software, La Jolla, CA) was used for all statistical analysis. Unpaired t-tests were used for comparisons between groups, differences were considered to be significant at the level of $p<0.05$.

\section{Results and Discussion}

\section{Determination of $\mathbf{C 6}$ glioma cell cfigureytotoxicity}

Cytotoxic activity of $\mathrm{ClO}$ extracts on $\mathrm{C} 6$ glioma cells were determined by MTT assay. L929 fibroblast cells were used to determine $\mathrm{ClO}$ extract's cytotoxic activity on normal cells. C6 glioma and L929 fibroblast cells were treated with different concentrations of $(0.02 \%$ to $1 \%)$ $\mathrm{ClO}$ extract for 24 and $48 \mathrm{~h}$. $\mathrm{ClO}$ extracts inhibited viability of $\mathrm{C} 6$ glioma cells in a dose and time dependent manner. On the other hand, L929 cells treated with various concentrations of $\mathrm{ClO}$ extract did not change cell viability for both 24 and $48 \mathrm{~h}$ treatment (Figure $1 \mathrm{a}$ and 1b). As shown in Figure 1a, $24 \mathrm{~h}$ treatment of $\mathrm{C} 6$ glioma cells with $\mathrm{ClO}$ extracts did not show any significant cytotoxic activity in lower concentrations such as $0.02 \%$ and $0.05 \%$. However, increasing concentrations of $\mathrm{ClO}$ started to inhibit proliferation of $\mathrm{C} 6$ glioma cells. The significant decrease in cell proliferation was observed at $0.125 \%$ concentration and $\mathrm{IC}_{50}$ was found $0.22 \%$ for $24 \mathrm{~h}$ treatment with $\mathrm{ClO}$ extract. $\mathrm{L} 929$ cell viability did not change even in the higher concentrations of $\mathrm{ClO}$ treatment (Figure 1a). The inhibitory effect of $\mathrm{ClO}$ extracts on C6 glioma cells were higher after $48 \mathrm{~h}$ treatment compared to $24 \mathrm{~h}$ (Figure $1 \mathrm{~b}$ ). Figure $1 \mathrm{~b}$ represents inhibitory effect of $\mathrm{ClO}$ extracts on $\mathrm{C} 6$ glioma cells and $\mathrm{L} 929$ fibroblast cells after $48 \mathrm{~h}$ treatment. C6 glioma cell viability decreased to $55 \%$ after treatment with $0.05 \% \mathrm{ClO}$ extracts. Cell cytotoxicity of $\mathrm{C} 6$ glioma cells were significantly increased at concentrations of $0.05 \%$ and above (Figure 1b). Treatment of C6 glioma cells with $1 \% \mathrm{ClO}$ extract resulted in $11 \%$ cell viability.

Table 1. Specific primer sequences used for qRT-PCR

\begin{tabular}{lll}
\hline Gene & Forward Primer & Reverse Primer \\
\hline$\beta$-actin & 5'-CATGTACGTTGCTATCCAGGC-3' & 5'-CTCCTTAATGTCACGCACGAT-3' \\
Cytochrome-c & 5'-CTTTGGGCGGAAGACAGGTC-3' & 5'-TTATTGGCGGCTGTGTAAGAG-3' \\
Caspase-3 & 5'-AGAGGGGATCGTTGTAGAAGTC-3' & 5'-ACAGTCCAGTTCTGTACCACG-3' \\
Caspase-9 & 5'-CTCAGACCAGAGATTCGCAAAC-3' & 5'-GCATTTCCCCTCAAACTCTCAA-3' \\
Caspase-8 & 5'-GTTGTGTGGGGTAATGACAATCT-3' & 5'-TCAAAGGTCGTGGTCAAAGCC-3' \\
Bax & 5'-CCCGAGAGGTCTTTTTCCGAG-3' & 5'-CCAGCCCATGATGGTTCTGAT-3' \\
Bcl-2 & 5'-GGTGGGGTCATGTGTGTGG-3' & 5'-CGGTTCAGGTACTCAGTCATCC-3' \\
\hline
\end{tabular}


$\mathrm{IC}_{50}$ concentration for $48 \mathrm{~h}$ treatment with $\mathrm{ClO}$ extract was calculated as $0.082 \%$. Moreover, treatment with all concentrations of $\mathrm{ClO}$ extracts did not show any cytotoxic effect on L929 cells (Figure 1b).
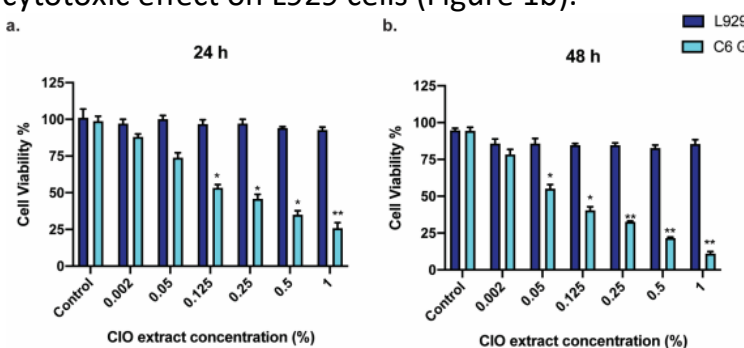

Figure 1. Percentage cell viability of $L 929$ and C6 glioma cells after treatment with $\mathrm{ClO}$ extracts for a) $24 \mathrm{~h}$ and b) $48 \mathrm{~h}$. Data are expressed as mean \pm standard deviation from three independent experiments. ${ }^{*} p<0.05,{ }^{* *} p<0.001$.

Biological activity of C. inophyllum oil extracts were also previously tested in different studies. A study by Ansel et al. (2016) tested cytotoxic activity of C. inophyllum oil extracts cytotoxicty on human keratinocytes (HaCaT) and normal dermal fibroblasts (ECACC). In both cell lines, $C$. inophyllum oil extracts did not show any significant cytotoxic activity in a concentration range from $1 \%$ to $0.125 \%$. Our results also revealed that $\mathrm{ClO}$ extracts were safe to be used in $\mathrm{L929}$ fibroblast cells in the concentration range of $0.02 \%$ to $1 \%$. The cytotoxic activity of $\mathrm{ClO}$ extracts was evaluated in different studies but most of these studies were focused on human skin cells (Ansel et al., 2016). However, literature on examining the impact of $\mathrm{ClO}$ extract on cancer cells were limited. A study investigating the in vitro anticancer of $C$. inophyllum ethanolic leaf extract on MCF-7 breast cancer cell lines found that $\mathrm{IC}_{50}$ of $120 \mu \mathrm{g} / \mathrm{mL}$ strongly inhibits MCF-7 cell growth. The same study was reported that the increase in cytotoxic activity of MCF-7 cells were also dependent on increasing concentrations of $\mathrm{C}$. inophyllum ethanolic leaf extract (Léguillier et al., 2015).

\section{ClO extracts inhibits $\mathbf{C} 6$ glioma cell proliferation}

The effect of $\mathrm{CIO}$ extracts on $\mathrm{C} 6$ glioma cell proliferation was determined using PCNA immunocytochemical staining. C6 glioma cells were treated with $\mathrm{IC}_{50}$ concentrations of $\mathrm{ClO}$ extracts for 24 and $48 \mathrm{~h}$. Then, immunostained cells were counted and PCNA positive cell rates were determined (Figure 2). CIO extract treatment significantly reduced $\mathrm{C} 6$ glioma cell proliferation both 24 and $48 \mathrm{~h}$ treatment. $24 \mathrm{~h}$ treatment with $\mathrm{ClO}$ extract resulted in 55.6\% PCNA positive cells while $48 \mathrm{~h}$ treatment decreased PCNA positive cell numbers to $30.3 \%$ (Figure 2). Sustained proliferative signaling is one of the key hallmarks of cancer (Hanahan \& Weinberg, 2011). Therefore, it is crucial to determine potential anti-cancer agents' effect on cell proliferation. It is known that phytochemicals are polyphenol rich natural compounds that derived from different plants (Upadhyay \& Dixit, 2015). C. inophyllum is a polyphenol rich plant and contains many different biologically active groups such as flavonoids and coumarins. These chemical groups are individually a great source of potential anti-tumor agents (Itoigawa et al., 2001). On the other hand, studies suggest even minor compounds in oil extracts might have great importance in order to synergistically act and inhibit cancer cell proliferation (Bakkali et al., 2006). Our results revealed that $\mathrm{CIO}$ extracts inhibits cell proliferation in a time dependent manner on C6 glioma cells. This inhibition could either be a result of synergistic activity of ClO extract's functional groups or individual activity of flavonoids and coumarins.
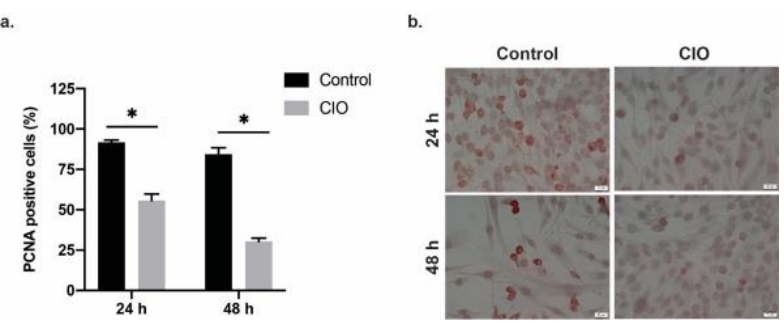

Figure 2. Effect of $\mathrm{ClO}$ extracts on proliferation of $\mathrm{C} 6$ glioma cells. a) PCNA positive cell rate of $\mathrm{C} 6$ glioma cells after 24 and $48 \mathrm{~h}$ treatment with $\mathrm{IC}_{50}$ concentration of $\mathrm{ClO}$ extracts. b) Bright-field microscope images of immunostained cells. ${ }^{*} p<0.05$

\section{Determination of $\mathrm{CIO}$ extract induced apoptotic activity on $\mathbf{C 6}$ glioma cells by TUNEL assay}

Immunocytochemical detection of $\mathrm{ClO}$ extracts apoptotic activity on $\mathrm{C} 6$ glioma cells showed by TUNEL assay. TUNEL method detects apoptotic cells that undergo extensive DNA degradation during the late stages of apoptosis (Kyrylkova et al., 2012). C6 glioma cells were treated with 24 and $48 \mathrm{~h} \mathrm{IC} 50$ concentrations of $\mathrm{ClO}$ extracts. Results showed that $\mathrm{ClO}$ extracts induces apoptosis on C6 glioma cells (Figure 3).

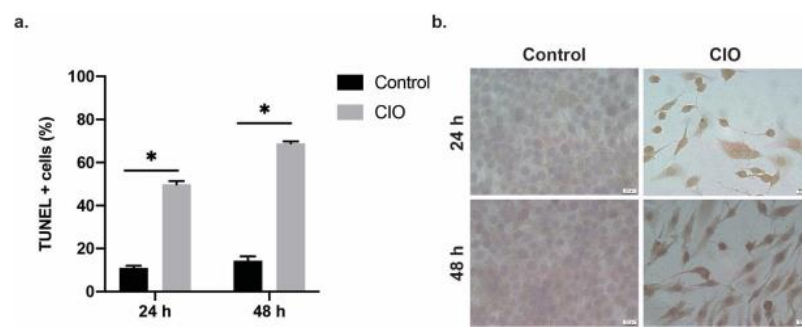

Figure 3. Detection of apoptotic C6 glioma cells treated with $\mathrm{ClO}$ extracts for 24 and $48 \mathrm{~h}$. a) TUNEL positive labeled cell percentage b) Bright-field microscope images of immunostained cells. ${ }^{*} p<0.05$.

Both 24 and $48 \mathrm{~h}$ incubation of $\mathrm{C} 6$ glioma cells with $\mathrm{ClO}$ extracts resulted in a significant increase in apoptotic cell number. TUNEL positive stained C6 glioma cell percentage was increased to $49.8 \%$ after $24 \mathrm{~h}$ treatment with $\mathrm{ClO}$ extracts. Moreover, apoptotic C6 glioma cell percentage reached $68.8 \%$ after $48 \mathrm{~h}$ treatment with $\mathrm{ClO}$ extracts. Untreated $\mathrm{C} 6$ glioma cells were used as controls. In contrast with $\mathrm{ClO}$ extract 
treated cells, apoptotic activity did not change in control group for 24 and $48 \mathrm{~h}$. Apoptosis is one of the most important events in cancer progression. Cancer cells are known for their resistance to apoptosis. Therefore, it is important to activate apoptosis in cancer cells in order to prevent tumor growth and cancer progression. Our results demonstrated on a cellular level that $\mathrm{ClO}$ extracts induces apoptosis on $\mathrm{C} 6$ glioma cells.

\section{Determination of apoptosis related genes expression levels on $\mathrm{CIO}$ extract treated $\mathrm{C} 6$ glioma cells}

TUNEL labeling assay results revealed that $\mathrm{CIO}$ extracts induces apoptosis on C6 glioma cells. In order to elucidate molecular base of $\mathrm{ClO}$ induced apoptosis induction, expression levels of key genes involved in intrinsic and extrinsic apoptosis pathway were investigated. For this aim, mRNA levels of cytochromec, caspase-3, caspase-9, caspase-8, bax and bcl-2 genes of $\mathrm{ClO}$ extract treated $\mathrm{C} 6$ glioma cells were determined by qRT-PCR. Since TUNEL labeling revealed $48 \mathrm{~h}$ incubation with $\mathrm{ClO}$ extracts increased apoptotic cell percentage to $68.8 \%$, gene expression levels of apoptosis related genes were determined after cells treated with $48 \mathrm{~h} \mathrm{IC}_{50}$ concentrations of $\mathrm{ClO}$ extracts. Differential gene expression levels were presented in Table 2. Results showed that $\mathrm{ClO}$ extract treatment induces both intrinsic and extrinsic apoptosis pathway on C6 glioma cells. Genes that activates intrinsic pathway of apoptosis were showed increased level of expression. Cytochrome-c is an important role to initiate intrinsic apoptosis pathway. Once it released from mitochondria to cytosol, it binds to apoptotic protease activating factor-1 and this event subsequently leads to formation of apoptosome complex (Arnoult et al., 2002). Our results showed that $\mathrm{ClO}$ extracts increased cytochrome-c expression 4.1 times than control.

Table 2. Relative mRNA expression levels of apoptosis related genes after $\mathrm{ClO}$ extract treatment on $\mathrm{C} 6$ glioma cells $(p<0.001)$

\begin{tabular}{ll}
\hline Gene & Relative Fold Change \\
\hline B -actin & 1 \\
Cytochrome-c & 4.1137 \\
Caspase-3 & 4.3866 \\
Caspase-9 & 6.2334 \\
Caspase-8 & 2.3667 \\
Bax & 3.0157 \\
BCl-2 & -0.8218 \\
\hline
\end{tabular}

Release of cytochrome-c from mitochondria depends on $\mathrm{Bcl}-2$ and $\mathrm{Bax}$ proteins activity. $\mathrm{Bcl}-2$ protein binds pro-apoptotic Bax to prevent pore formation and release of cytochrome-c from mitochondria (Naseri et al., 2015). Expression level of Bax was 3.01 times higher than control cells. On the contrary, $\mathrm{Bcl}-2$ relative mRNA expression was found to be -0.82 indicating the apoptosis activation and reverse relationship between $\mathrm{Bcl}-2$ and Bax. Moreover, caspase- 3 and caspase- 9 expressions were also increased 4.3 and 6.2 times, respectively. Activation of caspase- 9 also supports that
$\mathrm{ClO}$ extracts induces intrinsic apoptosis pathway. Despite lack of literature on $\mathrm{ClO}$ extracts apoptosis inducing activity on cancer cells, one study established that treatment of DLD-1 human colon cancer cells with pigments from $C$. inophyllum seed oil resulted in apoptosis induction and G2/M cell cycle arrest (Hsieh et al., 2018). A study by Shanmugapriya et al. (2017) also revealed that treatment of MCF-7 breast cancer cells with $C$. inophyllum fruit extracts decreased $\mathrm{Bcl}-2$ expression and increased Bax, cytochrome-c and p53 expressions. Taken together, our results were found to be consistent with the literature and it can be concluded that different extracts of $C$. inophyllum induces apoptosis on various cancer cell lines.

\section{Conclusion}

This study was aimed to investigate antiproliferative and apoptosis inducing activity of $\mathrm{ClO}$ extracts on C6 glioma cells. Our results demonstrated that $\mathrm{ClO}$ extracts significantly reduced glioma cell viability. Additionally, immunocytochemistry studies showed that cell proliferation decreases, and apoptosis induction was increased after $\mathrm{ClO}$ treatment. Apoptosis induction was also confirmed by qRT-PCR analysis. Overall, our results suggest that $\mathrm{CIO}$ might have a potential use in cancer treatment. However, further in vitro and in vivo studies investigating the molecular mechanisms of the anti-cancer activity of $\mathrm{ClO}$ extracts are required.

\section{References}

Ansel, J. L., Lupo, E., Mijouin, L., Guillot, S., Butaud, J. F., Ho, R., Lecellier, G., Raharivelomanana, P., \& Pichon, C. (2016). Biological activity of Polynesian Calophyllum inophyllum oil extract on human skin cells. Planta medica, 82(11/12), 961-966. https://doi.org/10.1055/s-0042108205

Arnoult, D., Parone, P., Martinou, J. C., Antonsson, B., Estaquier, J., \& Ameisen, J. C. (2002). Mitochondrial release of apoptosis-inducing factor occurs downstream of cytochrome $c$ release in response to several proapoptotic stimuli. The Journal of cell biology, 159(6), 923-929. https://doi.org/10.1083/jcb.200207071

Bakkali, F., Averbeck, S., Averbeck, D., Zhiri, A., Baudoux, D., \& Idaomar, M. (2006). Antigenotoxic effects of three essential oils in diploid yeast (Saccharomyces cerevisiae) after treatments with UVC radiation, 8-MOP plus UVA and MMS. Mutation Research/Genetic Toxicology and Environmental Mutagenesis, 606(1-2), 27-38. https://doi.org/10.1016/j.mrgentox.2006.02.005

Choudhari, A. S., Mandave, P. C., Deshpande, M., Ranjekar, P., \& Prakash, O. (2020). Phytochemicals in cancer treatment: From preclinical studies to clinical practice. Frontiers in pharmacology, 10, 1614. https://doi.org/10.3389/fphar.2019.01614

Delgado-López, P., \& Corrales-García, E. (2016). Survival in glioblastoma: a review on the impact of treatment modalities. Clinical and Translational Oncology, 18(11), 1062-1071. https://doi.org/10.1007/s12094-016-1497-x 
Dweck, A., \& Meadows, T. (2002). Tamanu (Calophyllum inophyllum)-the African, Asian, polynesian and pacific panacea. International journal of cosmetic science, 24(6), 341-348.

https://doi.org/0.1046/j.14672494.2002.00160.x

Ersoz, M., Erdemir, A., Duranoglu, D., Uzunoglu, D., Arasoglu, T., Derman, S., \& Mansuroglu, B. (2019). Comparative evaluation of hesperetin loaded nanoparticles for anticancer activity against C6 glioma cancer cells. Artificial cells, nanomedicine, and biotechnology, 47(1), 319-329.

https://doi.org/10.1080/21691401.2018.1556213

Hanahan, D., \& Weinberg, R. A. (2011). Hallmarks of cancer: the next generation. cell, 144(5), 646-674. https://doi.org/10.1016/j.cell.2011.02.013

Hanif, F., Muzaffar, K., Perveen, K., Malhi, S. M., \& Simjee, S. U. (2017). Glioblastoma multiforme: a review of its epidemiology and pathogenesis through clinical presentation and treatment. Asian Pacific journal of cancer prevention: APJCP, 18(1), 3. https://doi.org/10.22034/APJCP.2017.18.1.3

Hsieh, C., Lin, Y. W., Chen, C. H., Ku, W., Ma, F., Yu, H., \& Chu, C. (2018). Yellow and green pigments from Calophyllum inophyllum L. seed oil induce cell death in colon and lung cancer cells. Oncology letters, 15(4), 5915-5923. https://doi.org/10.3892/ol.2018.8052

Itoigawa, M., Ito, C., Tan, H. T. W., Kuchide, M., Tokuda, H., Nishino, H., \& Furukawa, H. (2001). Cancer chemopreventive agents, 4-phenylcoumarins from Calophyllum inophyllum. Cancer letters, 169(1), 15-19. https://doi.org/10.1016/S0304-3835(01)00521-3

Jaikumar, K., Mohamed, S. N. M., Anand, D., \& Saravanan, P. (2016). Anticancer activity of Calophyllum inophyllum L., ethanolic leaf extract in MCF human breast cell lines. International Journal of Pharmaceutical Sciences and Research, 7(8), $3330 . \quad$ https://doi.org/ 10.13040/IJPSR.0975-8232.7(8).3330-35

Kyrylkova, K., Kyryachenko, S., Leid, M., \& Kioussi, C. (2012). Detection of apoptosis by TUNEL assay. In Odontogenesis (pp. 41-47). Springer. https://doi.org/10.1007/978-1-61779-860-3 5

Léguillier, T., Lecsö-Bornet, M., Lémus, C., Rousseau-Ralliard, D., Lebouvier, N., Hnawia, E., Nour, M., Aalbersberg, W.,
Ghazi, K., \& Raharivelomanana, P. (2015). The wound healing and antibacterial activity of five ethnomedical Calophyllum inophyllum oils: an alternative therapeutic strategy to treat infected wounds. PloS one, 10(9), e0138602.

https://doi.org/10.1371/journal.pone.0138602

Livak, K. J., \& Schmittgen, T. D. (2001). Analysis of relative gene expression data using real-time quantitative PCR and the 2- $\triangle \Delta C T$ method. methods, 25(4), 402-408. https://doi.org/10.1006/meth.2001.1262

Naseri, M. H., Mahdavi, M., Davoodi, J., Tackallou, S. H., Goudarzvand, M., \& Neishabouri, S. H. (2015). Up regulation of $\mathrm{Bax}$ and down regulation of $\mathrm{Bc} / 2$ during 3NC mediated apoptosis in human cancer cells. Cancer cell international, 15(1), 55. https://doi.org/10.1186/s12935-015-0204-2

Raharivelomanana, P., Ansel, J.-L., Lupo, E., Mijouin, L., Guillot, S., Butaud, J.-F., Ho, R., Lecellier, G., \& Pichon, C. (2018). Tamanu oil and skin active properties: from traditional to modern cosmetic uses. OCL, 25(5), D504. https://doi.org/10.1051/ocl/2018048

Shanmugapriya, Chen, Y., Kanwar, J. R., \& Sasidharan, S. (2017). Anticancer activity and molecular mechanism of polyphenol rich Calophyllum inophyllum fruit extract in MCF-7 breast cancer cells. Nutrition and cancer, 69(8), 1308-1324.

https://doi.org/10.1080/01635581.2017.1367944

Susanto, D. F., Aparamarta, H. W., Widjaja, A., \& Gunawan, S. (2019). Calophyllum inophyllum: Beneficial Phytochemicals, Their Uses, and Identification. In Phytochemicals in Human Health. IntechOpen. https://doi.org/10.5772/intechopen.86991

Thakkar, J. P., Dolecek, T. A., Horbinski, C., Ostrom, Q. T., Lightner, D. D., Barnholtz-Sloan, J. S., \& Villano, J. L. (2014). Epidemiologic and molecular prognostic review of glioblastoma. Cancer Epidemiology and Prevention Biomarkers, 23(10), 1985-1996. https://doi.org/ 10.1158/1055-9965.EPI-14-0275

Upadhyay, S., \& Dixit, M. (2015). Role of polyphenols and other phytochemicals on molecular signaling. Oxidative medicine and cellular longevity, 2015. https://doi.org/10.1155/2015/504253 